\title{
Ikke blot en lære, men en åndsretning
}

På sporet af en narrativ personalisme hos danske baptister

\author{
Ph.d., cand.mag. i filosofi \\ Johannes Aakjer Steenbuch
}

\begin{abstract}
Since the foundation of the first Danish Baptist congregation in 1839, Danish Baptists have held widely different theological opinions. It may be argued, however, that many Danish Baptists have subscribed to what may be called a "narrative personalism". By this concept is meant a narrative conception of faith that sees personal history as being central. The "personal" should be distinguished from the purely subjective or individual, on the one hand, and the collective or general, on the other. Danish Baptist theologians such as the founding father, P.C. Mønster, P. Olsen and Kjell Kyrø-Rasmussen have in different ways expressed views that made the concrete relationships between persons of faith in the community of believers more fundamental than, e.g., written creeds and other dogmatic expressions of faith.
\end{abstract}

Keywords: Danish Baptists - Baptist theology - narrative personalism - P.C. Mønster - Julius Købner - P. Olsen - Kjell Kyrø-Rasmussen.

\section{Baptister, med småt "b"}

Det er ikke altid lige til at få hold på, hvad der egentlig kendetegner danske baptister ud over, selvfølgelig, bekendelsesdåben og menighedernes selvstændighed i forhold til staten. Der findes ingen fælles trosbekendelse eller andre nedskrevne retningslinjer for, hvad det vil sige at være rigtig "baptist". Der er derfor også gode grunde til at undgå at tale om fx "baptisme". I det følgende vil jeg dog slå ned på nogle grundtræk fra danske baptisters idéhistorie, som jeg alligevel mener, siger noget væsentligt.

Min påstand er, at danske baptister er kendetegnet ved en grundholdning, som jeg vil kalde "narrativ personalisme". Efter nogle eksempler fra baptisternes første år i det 19. århundrede præsenteres nogle nedslag hos to af de måske vigtigste danske baptistteologer i det 20. århundrede, P. Olsen (1865-1938) og Kjell Kyrø-Rasmussen (1920-1986). Slutteligt bringes nogle eksempler fra nyere skrivelser fra Baptistkirken i Danmark, samt et "case"-eksempel, idet jeg kort diskuterer Købnerkirkens (baptistkirken på Amager) beslutning om 
at afskaffe kirkelige vielser som en løsning på debatten om homoægteskaber.

Jeg har måttet foretage en del udeladelser. Blandt andet er der ikke blevet plads til selvstændige afsnit om fx Knud Wümpelmann eller Johannes Nørgaard (1893-1977). Sidstnævnte skal dog citeres her: "Baptismen er ikke blot en Lære, men en Udformning af det kristne Liv, en Aandsretning." Udeladelsen skyldes ikke mindst, at den af Eduard Geismar influerede Nørgaard i høj grad må siges at have et mere individualistisk begreb om, hvad vi skal forstå ved personlig tro, trods en veludviklet pneumatologi. Dog bør nævnes Nørgaards indføring i sakramentsteologi i Den kristne Daab, som afsluttes under titlen "Personlige Vidnesbyrd om kaldet til Omvendelse og Daab" med et langt kapitel med små personlige selvbiografier af danske baptister ledsaget af billeder og underoverskrifter såsom "Jeg havde vist altid nok villet være en Kristen", "Hans Kors forkynder et evigt Haab", "Min Frelsessag kom til at staa som min store Anledning", "Ikke flasket op med Baptisme", "Jeg er født og opvokset i et Baptisthjem", "Mine første Ungdomsaar var nok den mest ubekymrede Tid", "Et personligt Standpunkt for Jesus" og så videre. ${ }^{2}$ Disse småbiografier er gode eksempler på, hvordan "personlig tro" forstås biografisk og narrativt.

Der er med "narrativ personalisme" ikke så meget tale om en bestemt dogmatik, som der er tale om, hvad man måske kan kalde "meta-teologi", altså de rammer for teologisk reflektion, som hos baptister har et bestemt kirke- og skriftsyn som fundament. Med "narrativ personalisme" skal forstås en grundholdning, som lægger vægt på en fortællende tilgang til troen, samt det personlige, forstået i modsætning til det rent subjektive eller private såvel som det rent kollektive. Med det "personlige" menes her det enkelte menneske i sine konkrete relationer til Gud og andre mennesker.

I nyere tid er det blandt andre amerikanske baptistteologer såsom James McClendon, Glen H. Stassen og David P. Gushee samt mennonitter som John Howard Yoder og J. Denny Weaver, der har forsvaret forskellige former for narrative og personalistiske tilgange. ${ }^{3}$ Pointen er lidt forenklet, at det "personlige forhold" til Gud kommer

1. Johannes Nørgaard ifølge Bent Hylleberg, m.fl., Et kirkesamfund bliver til: Danske baptisters historie gennem 150 à (København: Føltveds Forlag 1989), 304. Se også Bent Hylleberg, "Knud Wümpelmann" i Journal of European Baptist Studies, (Prag: IBTS 3/2002), 5-20.

2. Johannes Nørgaard, Den kristne Daab: Sakramentspørgsmaalet betragtet paany (Holbæk: Dansk Baptist-Forlag 1944). Se også Johannes Nørgaard, På vej til en livsopgave (Aalborg: Baptisternes Forlag 1964).

3. Se fx H. Stassen og David P. Gushee, Kingdom Ethics: Following Jesus in Contemporary Context (Illinois: IVP Academic 2003), 57 
før dogmatikken, og at teologi derfor kun sekundært er en rationel refleksion over, hvad troen betyder abstrakt set. Teologiske discipliner som systematisk teologi og dogmatik er refleksioner over kirkens historie(r), med udgangspunkt i Bibelen. Den enkelte menighed finder sin identitet $i$ historiefortællinger snarere end i en dogmatisk trosbekendelse.

At reflektere over troen betyder først og fremmest at fortælle historier - både Guds historie, som den findes i Bibelen, og menneskers historie, som den belyses af Guds historie i kraft af forkyndelsen af evangeliet. Ifølge McClendon må teologi derfor udfoldes som biografi (eller omvendt, "biography as theology"). ${ }^{4}$ Teologien udfoldes ved at beskrive menneskers liv og levned og derigennem deres trosforestillinger. Af samme grund starter McClendons systematiske teologi i tre bind med etikken. Ifølge McClendon har baptister alt for ofte har ladet deres teologiske dagsorden sætte af problemstillinger, som var dem fremmede, fx debatten blandt reformerte teologer om monergisme og synergisme. Baptister bør i stedet interessere sig for, hvad der er særligt for traditionen, ikke mindst som den kan spores tilbage til reformationens radikale fløj. McClendon og andre taler således om "small b baptists" for at pege på en tradition, som er bredere og mere forskelligartet end den kirkeretning, der i USA kaldes "Baptists" (med stort B)..$^{5}$ Det er tankegange som denne, jeg mener at kunne genfinde historisk og aktuelt hos danske baptister, ikke mindst i forholdet til trosbekendelser.

\section{De første år}

Den første danske (og skandinaviske) baptistmenighed, "Daabsmenigheden i Kjøbenhavn", blev stiftet af den sjællandske gravør P.C. Mønster i 1839, som var leder af menigheden indtil 1853. Mønster kom først hos Grundtvig, indtil Grundtvig angiveligt i en prædiken skulle have forsvaret en dobbelt forudbestemmelse. ${ }^{6}$ Mønster tog afstand fra Grundtvigs syn på folk og kirke, og efterhånden blev han

4. James McClendon, Biography as Theology: How Life Stories Can Remake Today's Theology (Nashville: Abingdon 1974).

5. James McClendon, Systematic Theology: Ethics (Nashville: Abingdon Press, 1986), 23.

6. Ifølge Lindberg til Helland 11.9.1838; Enoch Svee, "Copie af 'Copie af et Brev til Herr. Pastor Grundtvig, i Anledning af en Prædiken, holdt af ham paa 2den Søndag i Faste 1838'." 
også overbevist om urigtigheden af den traditionelle barnedåb. ${ }^{7}$ I 1839 blev Mønster som 42-årig bekendelsesdøbt i Lersøen (nu Lersøparken). Den slags aktiviteter var ulovlige, og Mønster måtte i fængsel i alt fem gange de følgende år.

\section{Mønster og trosbekendelsen}

Mønster og hans følge blev døbt af den tyske baptistmissionær Johann Gerhard Oncken (1800-1884). Oncken var foregangsmand for stiftelsen af baptistmenigheder rundt omkring i Nordeuropa og kan sammen med tyske Wilhelm Lehmann (1799-1882) og danske Julius Købner (1806-1884) betegnes som kirkefader for mange nordeuropæiske baptistmenigheder.

Onckens indflydelse i Danmark var klar, men Mønster og hans menighed havde dog sin egen forståelse af centrale punkter, herunder dåbssyn og udvælgelseslære, hvor Mønster forsvarede en mere traditionel luthersk position mod Onckens reformerte teologi. For Mønster var det samtidig afgørende, at baptisterne ikke skulle have nogen nedfældet trosbekendelse.

Det er Princip i vort baptistiske Troessamfund ikke at have nogen skreven Troesbekjendelse, enten som Uddrag af eller grundet paa det nye Testamente, der heelt og holdent er vor eneste Troesregel [...] Jeg kan saaledes ikke fremlægge nogen anden Troesbekjendelse end den hellige Skrift, som gjældende for Menigheden (Hylleberg, m.fl. 1989, 22).

Heller ikke dette princip var hentet fra de hamborgske baptister, der, som de engelske baptister, havde deres egen trosbekendelse. Afvisningen af at have en skreven trosbekendelse kan måske forstås som et opgør med den grundtvigske vægtlægning på bekendelsen som "ord talt af Herrens egen mund". I hvert fald var det for Mønster ikke en mængde skrevne artikler, der konstituerede menigheden, men den enkeltes personlige bekendelse af sin tro. Afvisningen af en skreven trosbekendelse havde derfor betydning for hvordan man kunne optage nye medlemmer i menigheden. Trosbekendelsen består ikke i svar på fastlagte spørgsmål, men i, at den, der skal døbes gives anledning til at fortælle sin livshistorie:

Førend vi i Menigheden optager nogen Katekumén, maa denne først for Menighedens indviede Lærer eller Ældste kunne aflægge en Troesbekjendelse, men denne bestaar ikke i nogle forud bestemte Spørgs-

7. Arne Jensen, Julius Købner: Grundlaggeren af den forste frikirke i Danmark (Dansk Baptist-forlag: København 1947), 29. 
maal eller Svar, men tildels deri, at Katekuménen gives Anledning til at fortælle sit Levnedsløb, som det har været saavel før som efter hans Omvendelse, samt at gøre Regnskab for hans Troe og Haab til Salighed, og naar det da skønnes, at hans Troe er grundet paa Kristus, som død for hans Synder og opstanden for hans Retfærdighed, efter forudgangen Anger, Bod og Omsindelse, antager Læreren en saadan til Daab (Hylleberg, m.f. 1989, 22).

Mønsters principielle afvisning af en nedskrevet trosbekendelse måtte dog vige, efterhånden som de tyske baptister overtog styringen af de danske baptistmenigheder. Mønster fungerede som leder af de københavnske baptister de første år, men måtte overlade ledelsen til A.P. Førster (1819-1889), der overtog lederskabet efter Mønster i 1848. Førster blev i 1842 af Oncken sendt til England, hvor han tilknyttet "The Primitive Evangelical Baptists" studerede reformert teologi. Mønsters lutherske linje måtte vige for en mere calvinsk. ${ }^{8}$

\section{Købner og calvinismen}

Efter Førster kom Købner i 1865 på Onckens anbefaling til København fra Hamborg. Julius (Salomon) Købner var af jødisk slægt og blev født i Odense i 1806, men flyttede som 18-årig til Lübeck. Her modtog han undervisning i kristendom af den reformerte præst Dr. Geibel (Jensen 1947, 14). I Hamborg kom han i kontakt med Onckens baptistmenighed og blev døbt i 1836 . Købner blev en betydningsfuld missionær i Tyskland og Skandinavien (Jensen 1947, 25).

Købner overtog en reformert teologi, hvor kontinuiten mellem den gamle og den nye pagt kom til at tjene som nøgle til at forstå hans egen identitet som kristen af jødisk afstamning (Jensen 1947, 45). Købner skriver: "Jeg skammer mig ikke ved at blive kaldt Kalvinist. Jeg højagter Kalvin, og den reformerte Kirke har fra Begyndelsen været bedre end den lutherske. Vi Baptister var enige med den i de fleste Læresætninger." (Hylleberg, m.fl. 1989, 114). Udvælgelsen er baptisternes lærdom, understregede Købner, som heller ikke delte Mønsters principielle modstand mod trosbekendelser (Arne Jensen 1947, 66). Således indførtes på en konference i 1849 de hamborgske baptisters bekendelse fra 1847, med et reformert præg, i de danske baptistmenigheder.

Selvom de danske baptistmenigheder opstod i kølvandet på de gudelige vækkelser, havde man et ambivalent forhold til "vækkelser",

8. Se Bent Hylleberg, http://www.baptistkirken.dk/fileadmin/user/filer/dokumenter/Om_baptister/Historie_2_Foerster.pdf(besøgt 03.05.15). 
måske blandt andet som resultat af en "hypercalvinsk" forståelse udvælgelseslæren, som betød, at mission egentlig ikke handlede så meget om at omvende folk som at finde Guds udvalgte (Hylleberg, m.fl. 1989, 48). Hvor grundtvigianerne populært sagt ville vække den slumrende rest af gudbilledlighed i mennesket, og mens Indre Mission ville omvende den fortabte synder, ville baptisterne høste frugten af Guds selvsåede Ord. Marius Larsen, Købners efterfølger i Kristuskirken, bemærkede i 1896, at "Vækkelser er den Hellige Aands Værk; alt andet er uægte. De danske Baptister holde ikke af Ordet "Vækkelse". Det er maaske, fordi de have set for lidt Kjærne, for megen Skal." (Marius Larsen ifølge Hylleberg, m.fl. 1989, 164). Bemærkningen minder om, at omvendelse ikke kunne adskilles fra det fortløbende, konkrete liv i menighederne. Et helligt liv var afgørende, omend den såkaldte "fuldkommenhedslære" med bred tilslutning blev afvist af blandt andre Mønster i 1846 (Hylleberg, m.fl. 1989, 31).

Købners til tider strenge linje udelukkede ikke en vis økumenisk ånd: Alle troende i hele verden er mine brødre i Kristus, skriver Købner, "enten de saa er Katolikker, Lutheranere, Reformerte o.s.v." (Jensen, 80). Der var dog grænser for tolerancen. Således kritiserede Købner i fire breve skarpt Aalborgs baptistmenigheds bekendelse fra 1852, forfattet af Christian Westerby, som var præget af en luthersk forståelse af flere centrale punkter (Hylleberg, m.fl. 1989, 49). Der var altså fortsat betydelige uenigheder om $\mathrm{fx}$ nadversyn, forholdet mellem lov og evangelium, samt behovet for at bygge kapeller, missionsarbejdets art og så videre, som kom til at medvirke til splittelser mellem de danske baptistmenigheder. ${ }^{10}$

I sin lille afhandling om forholdet mallem dåb og nadver forsvarede Købner en lukket kommunion, med henvisning til en forståelse af bekendelsesdåben som indgang til menigheden og derfor også som forudsætning for deltagelse i nadveren. ${ }^{11}$ Men én ting er forholdet til menigheden, noget ganske andet det åndelige forhold til Gud og hans udvalgte folk, som findes blandt alle kirkeretninger. Købner skriver:

Der findes kristne, som ikke har andet for Øje end Menighedens Legeme; hvis Løsen er: „Kirke, Kirke!” Der findes andre, som ikke vil vide om noget andet end Kristendommens Aand, og som derfor optræder

9. Jf. fx den engelske "Particular Baptist" John Gill (1697-1771). Se Peter Toon, The Emergence of Hyper-Calvinism in English Nonconformity, 1689-1765 (London: The Olive Tree 1967), 70-85.

10. Se også N. Larsen, En Conferentse af danske Baptister, afholdt i Kapellet paa Vandløse Mark, den 26de September 1863 (Nakskov: Reinhard Kjeldskov 1863).

11. Julius Købner, Forbindelsen mellem Daab og Nadvere (København: Dansk Baptist-forlag 1900). 
fjendtligt opløsende mod enhver Menighedsforbindelse og hver Menighedsorden. Begge har forvildet sig. Lad Guds Ord staa fast: „Et Legeme og en Aand"; lad begge beholde det Værd, som Gud har tillagt dem. At lade begge beholde deres forskellige Værd og ikke sammenblande dem med hinanden — det er det rette (Købner 1900, 19-20).

Der findes med andre ord både et horisontalt og et vertikalt aspekt, hvor der på én gang skal holdes fast i det kirkelige fællesskab såvel som det personlige (her forstået som det individuelle) forhold til Gud. Vi kan altså hos Købner finde eksempler på den dobbelte afvisning af kollektivisme såvel som individualisme. Trods en høj grad af dogmatisk bevidsthed fulgtes denne tanke af en afvisning af ørkesløse diskussioner om dogmatikken: "Hovedsagen er ikke at mene dette eller hiint, og heller ikke at have den rette Mening; Hovedsagen er at være gjenfødt og at elske Jesus.” (Købner ifølge Hylleberg, m.fl. 1989, 112). Købner afviste af samme grund, at det skulle være muligt at afgøre samvittighedsspørgsmål endeligt: "Een Kristen mener, at hans Samvittighedsoverbevisning er den rette efter Guds Ord, og en anden tror, at hans er den rette efter det samme Ord. Begge er feilbare Mennesker, og der er ingen ufeilbar, inspireret Apostel, der kan afgjøre deres Trætte." (Jensen 1947, 66).

Mod Onckens ønske om en centraliseret kirkeledelse forsvarede Købner måske af samme grund efterhånden et mere demokratisk menighedsbegreb: "Vort Barndoms Begreb var Autoritet og Lydighed, og vi var villige til at underkaste os Autoritet. $\mathrm{Nu}$ er vi imidlertid blevet ældre og har Erfaring bag os. Autoritet og Underkastelse passer os derfor ikke mere. Derfor maa vi have andre Forhold; der er ingen Fraktion iblandt os, som vi skal underkaste os." (Jensen 1947, 58). Det var dette demokratiske menighedsbegreb, som blev normdannende fremover. I praksis synes dette at have medvirket til, at Mønsters oprindelige anti-dogmatiske syn på trosbekendelser efterhånden blev det almindelige (som den tyske indflydelse ebbede ud, blev Mønster også officielt rehabiliteret).

Apostolicum blev dog brugt som pædagogisk redskab i fx Knud Wümpelmanns Vi tror (1966) og er inkluderet i seneste udgave af danske baptisters salmebog fra 1989 som nr. 697 - uden djævleforsagelsen og med det oprindelige "jeg tror" (credo) i stedet for "vi tror". ${ }^{12}$ Den lille udgivelse Noget godt i ryggen - baptister på vej ind $i$ et nyt årtusind fra 2000 indeholder også en række kortere artikler af be-

12. Knud Wümpelmann, Vi tror - Kristendomskundkab for unge (Aalborg: Baptisternes Forlag 1966); Salmebog for de danske baptistmenigheder (Det danske Baptistsamfund 1989). 
kendelsesskriftsagtig karakter. ${ }^{13}$ Pointen er altså ikke, at Mønsters principielle afvisning af nedskrevne trosbekendelser blev ophøjet til officielt "dogme", men blot at vi i dansk baptisthistorie kan finde spor af, hvad jeg har kaldt "narrativ personalisme", som gør, at trosbekendelserne ofte ikke har haft nogen central rolle i menighedernes liv og selvforståelse. Dette bliver især klart med P. Olsen, som vi skal kigge på i det følgende.

\section{Et personligt forhold}

En vigtig skikkelse blandt danske baptister i første halvdel af det 20. århundrede var Peter Olsen (1865-1938), præst (menighedsforstander og prædikant) og forfatter til en række bøger, samt forstander på baptisternes prædikantskole i Tølløse og folkehøjskolen i Gistrup.

P. Olsen havde som ung sin gang hos grundtvigianerne og i Indre Mission, selvom han tidligt var blevet overbevist om, at baptisterne havde ret i deres anskuelser. P. Olsen forklarer at han hos baptisterne savnede "de ideelle interesser", som han kunne finde hos grundtvigianerne. Da han så alligevel blev baptist, blev et væsentligt anliggende for P. Olsen "folkeoplysning" af danske baptister, som det i øvrigt også havde været for Julius Købner. Som Bent Hylleberg formulerer det, var en af P. Olsens væsentligste indsigter, at "en kirke i mission må leve i en åben vekselvirkning med den kultur, kirken ønsker at præge." 14

\section{Gennem Tvivl}

P. Olsens forfatterskab spændte vidt og omfattede i 1916 en salmebog til erstatning af Købners, samt et lejlighedsskrift om Martin Luther i anledning af reformationsjubilæet i 1917, og i 1925 en slags katekismus under titlen Hovedpunkter af den kristne Troslare. ${ }^{15}$ Længe før skrev P. Olsen under pseudonymet Johannes Bakkeby bogen Gennem Tvivl - Breve til to unge Tvivlere, en fiktiv brevveksling mellem en troende mand og to unge kvinder om centrale trosspørgsmål, mate-

13. Bent Hylleberg, m.fl., Noget godt i ryggen - baptister på vej ind $i$ et nyt årtusind fra 2000 (København: Føltveds Forlag 2000).

14. P. Olsen ifølge Hylleberg, http://www.baptistkirken.dk/fileadmin/user/filer/ dokumenter/Om_baptister/Historie_6_Olsen.pdf (besøgt 03.05.15).

15. P. Olsen, Martin Luther og hans reformation: Et lejlighedsskrift (Dansk BaptistForlag 1917). 
rialismen, fremskridtet m.v. ${ }^{16}$ Forordet afslører, at det nok i høj grad var P. Olsens egen kamp med at få modernitet og kristendom til at gå op, der kom til udtryk i Gennem Tvivl: "Disse Breve rummer over tyve Aars Oplevelser. Først Kampe, siden rolige Overvejelser. [...] alt, hvad de indeholder, er levet."

Ikke mindst darwinismen og materialismen havde været en anstødssten for P. Olsen. Han kom dog efterhånden frem til den opfattelse, at kristendommens udsagn om mennesket kun har vægt for så vidt, at kristendommen er sit eget bevis, som er principielt uvidenskabeligt: "Thi hvad Kristendommen gennem dens Stifters Person og gennem det enkelte Menneskes Erfaring bevidner sig selv at være, det kan jo kun være Genstand for Tros-Vished." (Bakkeby (Olsen) 1913, 83). Bibelens sprogbrug er i vidt omfang billedligt og angår først og fremmest menneskers personlige trosforhold, snarere end abstrakte dogmer. Udviklingslæren må anerkendes, ikke fordi den kan bevises, for det er der i princippet intet, der kan, men fordi den løser langt flere problemer end andre hypoteser (Bakkeby (Olsen) 1913, 78).

P. Olsens sandhedsbegreb er pragmatisk. I Gennem Tvivl medgiver Johannes Bakkeby sin korrespondents veninde "Frk. Paula", at der kan være sandhedselementer $i$ alle religioner. Men kristendommen er "den sandeste" af religionerne, da den i en kamp med "aandelige Vaaben" må være den stærkeste (Bakkeby (Olsen) 1913, 68). I sekstende kapitel af Gennem Tvivl fremgår det, at, "Frk. Paula" har hørt et foredrag om "Dogmefri Religion". P. Olsen har muligvis Harald Høffdings religionsfilosofi i tankerne. Johannes Bakkeby giver Frk. Paula ret i, at en dogmefri religion nok kunne være værdifuld, hvis den var mulig. Men hvis Gud virkelig har vist sig i Jesus, så må hans liv og lære også tages alvorligt.

Jesus Kristus, den største Personlighed, der er traadt os Mennesker i Møde, er paa een Gang Gud og det ideale Menneske aabenbaret. Personer har Historie, Personer kan make history, som Englænderne siger, en Personlighed er aldrig noget flydende og ubestemt. Dersom De tænker den Tanke til Bunds, vilde De maaske finde det rimeligt, at Kristendommen har netop de Dogmer, den har (Bakkeby (Olsen) 1913, 127).

Kristendommen er et personligt forhold til Jesus Kristus. P. Olsen delte af samme grund P.C. Mønsters principielle skepsis over for nedskrevne trosbekendelser: "Hverken Trosbekendelse, Kirke, Pave eller egne religiøse Følelser kan være Autoritet i Spørgsmaalet om, hvad

16. Johannes Bakkeby (P. Olsen), Gennem Tvivl-Breve til to unge tvivlere (København: Pios Forlag 1913). 
oprindelig Kristendom var." Det Nye Testamente er det "litterære Nedslag" i den første kristne menigheds indre og ydre liv. Men det er Jesus selv, der er autoritet for troen: "Det er Ham, vi tror paa. Det ny Testamente er Autoritet, fordi Han er Autoritet." (P. Olsen ifølge Hylleberg, m.fl. 1989, 272). Den systematiske teologi er ikke kristendommens fundament, men udledes af Kristi person, som er kernen i kristendommen.

At det er "personer", der skaber historien, var en grundantagelse i Luther-biografien, idet P. Olsen antog den vist for samtiden udbredte opfattelse, at Luthers reformatoriske ærinde måtte forstås ud fra Luthers person: "Den lutherske Reformation er efter sit inderste Væsen en Personalhistorie omsat i Kirke- og Verdenshistorie." Deri ligger både dens fortrin og begrænsning, forklarer P. Olsen. Den lutherske reformation kan kun forstås "ud fra den store Reformator selv, hvad han var, og hvad han oplevede, indtil han traadte frem paa Historiens Skueplads." (Olsen 1917, 3).

\section{Personlighed er den højeste tilvarelsesform}

I Hovedpunkter af den kristne Troslere fra 1925 forsøgte P. Olsen sig med en kortfattet fremstilling af kristendommens hovedpunkter, uden særlig vægt på de ting, der var særegne for baptisterne. ${ }^{17}$ Julius Købners forkærlighed for den reformerte teologi bekræftes dog af P. Olsen, som fastslår, at baptisterne "henhører til den reformerte Kirkeafdeling" (P. Olsen ifølge Hylleberg, m.fl. 1989, 226). En striks forstålse af den dobbelte forudbestemmelse afvises dog. Vi kan ikke opgive troen på "vor Villies Frihed, uden at store Livsværdier lider Skade for os." (Olsen 1925, 28). Men viljen kan omvendt ikke tænkes uafhængigt af viljesgrunde, ligesom virkninger i naturen ikke kan tænkes uafhængigt af årsager. Abstrakte spørgsmål om viljens frihed løses kun i konkret praksis: "først naar vi ved Jesus Kristus er blevet ført ind i Samfundet med Gud, lærer vi ud fra personlig Oplevelse, hvad Guds Forsyn virkelig er." (Olsen 1925, 43).

Som i Gennem Tvivl gøres det i Hovedpunkter klart, at kilden til troslærens indhold er åbenbaringen ved Jesus Kristi person: "Hele den første Forkyndelse af Evangeliet gik altsaa tilbage til Jesus Kristus og kun til ham. Han "er" Kristendommen." (Olsen 1925, 22). Kristus selv er troslærens kilde, som forklaret ved Helligånden og Det Nye Testamente - men altså netop læst som en åbenbaring af Kristus og ikke som "Paragraffer" for "alle mulige Tilfælde i en Kristens indre og ydre Liv" (Olsen 1925, 23; 104-105).

17. P. Olsen, Hovedpunkter af den kristne Troslare (Holbæk: Dansk Baptist-Forlag 1925), 1 
F.C. Krarups opfattelse af religion som en almenmenneskelig ærefrygt for grundlæggende livsbetingelser, overtages af P. Olsen, som dog specificerer, at som sådan må religion forstås som form uden indhold. ${ }^{18}$ Kun med åbenbaringen gives religionen et indhold - og dette indhold er altså Kristus selv (Olsen 1925, 13):

Det staar jo fast, at Kristendommen kom ind i Verden med Jesus Kristus. Før var den der ikke. Der var altsaa heller ingen kristen Tro, og derfor heller ingen kristen Troslære. Jesu Kristi Person, hans Ord, hans Liv, hans Lidelse, Død og Opstandelse er Kristendommens centrale Kendsgerninger, og at forkynde Kristendommen er at forkynde disse Kendsgerninger (Olsen 1925, 21).

En subjektiv troslære, som kun har den menneskelige bevidsthed til sin kilde, kan ikke være en kristen troslære, men er blot almenmenneskelig religiøsitet, skriver P. Olsen (Olsen 1925, 20-21). Ikke desto mindre er "den kristne Erfaring af den guddommelige Virkelighed" afgørende for at kunne forstå indholdet af troslæren. Ingen bliver kristen i "al almindelighed" ${ }^{19}$ Kristendom er derfor også først og fremmest et konkret levet liv - forstanden kommer i anden række (Olsen 1925, 13).

Blandt kristendommens store tænkere nævnes Athanasius, Augustin, Thomas, Calvin, Melanchton, samt nogle i dag ret ukendte amerikanske baptistteologer, Hovey og Mullins. Derudover nævnes Schleiermacher, Th. Haering, samt H.L. Martensen (Olsen 1925, 9). Sidstnævnte spiller en stor rolle i Hovedpunkter, som på visse punkter nærmest kan kaldes en lommebogsudgave af Martensens Christelige Dogmatik, selvom P. Olsen forholder sig skeptisk til den spekulative teologi. Fx synes skellet mellem teologiens sandhed og (manglende) adækvathed at være overtaget næsten ordret fra dogmatikken sammen med den konklusion, at teologien aldrig endeligt kan bringe sin genstand på formel (Olsen 1925, 27).

Som Martensen advarer P. Olsen i Gennem Tvivlsamtidig mod den panteisme, som uundgåeligt findes i al "dogmefri Religion" (Bakkeby (Olsen) 1923, 127). Martensen afviste Kants og Schleiermachers subjektivisme som former for panteisme for i stedet at sætte et personbegreb, hvor det menneskelige subjekt forstås i sine objektive relationer til noget andet, andre personer og Gud. Som Martensen pointerede P. Olsen, at det gudbilledlige ved mennesket ikke, som

18. F.C. Krarup, Skrift og Tro, en Undersøgelse af Forholdet mellem Religion og Theologi i Det Nye Testamente (København: Pios Forlag 1907).

19. P. Olsen ifølge Hylleberg, http://www.baptistkirken.dk/fileadmin/user/filer/ dokumenter/Om_baptister/Historie_6_Olsen.pdf (besøgt 03.05.15). 
hos fx Grundtvig, er sproget, men personlighed: "Personlighed er den højeste Tilværelsesform, vi kender” (Olsen 1925, 28).

\section{P. Olsens kirkesyn}

Fordi Kristus er kristendommen, kan Helligånden, og derfor menigheden, heller ikke forstås uafhængigt af Kristi person: "Helligaandens Komme og Forbliven hos Menigheden er ikke sideordnet med Jesu Komme og Gerning; det er en Fortsattelse deraf." (Olsen 1925, 21). Kirken er derfor ikke et abstrakt eller rent "åndeligt" fællesskab, men et fællesskab af personer i konkrete menigheder. I Det Nye Testamente tales kun om lokale menigheder, benævnt ud fra de byer eller landsdele, hvor de havde hjemme, hævder P. Olsen, som konkluderer, at "det gængse nytestamentlige Menighedsbegreb kan ikke bestemmes anderledes end som et stedligt Samfund af Kristustroende" (Olsen 1925, 113).

De kirkelige embeder er derfor også knyttet til den konkrete, lokale menighed: "Noget Embede over de stedlige Menighedsembeder har det ny Testamente intet Spor af, altsaa fraregnet Apostelembedet, som jo ikke var et blivende. Menighederne var alene sammenknyttet ved samme Tro og Liv og ved den fælles Kærlighed." (Olsen 1925, 114). Menighedssynet får betydning for synet på kaldet til prædikant, som nok er et "indre Kald", mens der også skal en "Menigheds Stadfæestelse af Kaldet Til.” (Hylleberg, m.fl. 1989, 298-299).

Selvom menigheden skal forstås som et stedligt samfund af kristustroende, er den dog "noget langt højere end en Forening". De nytestamentlige beskrivelser af menigheden som Kristu legeme, hustru og brud, bør lede tanken videre fra den enkelte menighed til helheden, skriver P. Olsen (Olsen 1925, 113). Den enkelte menighed må derfor også forstå sig selv som led i en større historie, hvor Helligånden i menigheden forstås i forlængelse af "Jesu Komme og Gerning" (Olsen 1925, 21). Dette skal forstås ud fra såvel et fortidigt perspektiv som et fremtidsperspektiv. Jesu tale om "Guds rige" skal ikke kun forstås rent eskatologisk (Olsen 1925, 108). Guds rige på jorden indstiftes i og med Jesu person og er derfor også delvist en realitet, jf. Jesu ord i Luk 17,21. Dog afholder P. Olsen sig fra at identificere Guds rige med en kirkelig organisation eller en bestemt verdslig orden: "Hvor Guds Navn bliver helliget, og hvor hans Villie sker, der er hans Rige, hans Herredømme til Stede." (Olsen 1925, 110). Den kristne menighed er derfor også kun et medium for Guds rige:

Guds Rige og Menigheden er ikke det samme, for saa vidt vi da ved "Menigheden" tænker paa Organisation. Vi kan bedre sige, at efter det ny Test. er Menigheden den Form, hvorunder Guds Rige, altsaa Guds 
Herredømme, praktisk skal forkyndes og udbredes og opbygges (Olsen 1925, 112).

Dertil skal lægges det eskatologiske perspektiv, at nok er Guds rige indstiftet, men endnu ikke udfoldet: "Sagen er, at Guds Rige har en lang Historie." (Olsen 1925, 109-110). Guds rige skal for P. Olsen forstås ud fra dets fremtidshistorie, som vi lever under, men hvis fuldendelse dog endnu er tilbage. Hans personalisme skal derfor ikke forveksles med fx den donatisme, som blandt andre Urbanus Rhegius tilskrev reformationstidens døberbevægelser.

\section{Hvad skal vi med kirken?}

En anden af de danske baptisters teologiske profiler i det tyvende århundrede er Kjell Kyrø-Rasmussen (1920-1986), præst i Aarhus, København og Tølløse og forfatter til flere bøger om kirke og kristendom. Kyrø-Rasmussen var økumenisk engageret og forsvarede en grad af det, der er blevet kaldt en "åben baptisme" med mulighed for overført medlemskab samt indførslen af et ritual for barnevelsignelse og lignende tiltag. Selvom personbegrebet ikke optager så meget plads som hos P. Olsen, findes der hos Kyrø-Rasmussen træk af en slags personalistisk menighedsbegreb, hvor tanken om, at mennesket må forstås i sine konkrete relationer til Gud og andre mennesker er afgørende.

\section{Både individ og kollektiv}

Indflydelsen fra den engelske biskop og missionsteolog Lesslie Newbigin og andre engelske teologer er eksplicit, ikke mindst i bogen Hvad skal vi med kirken? fra 1967, hvor Kyrø-Rasmussen gav sit bud på et grundlæggende kirkesyn. ${ }^{20}$ Bogen var blandt andet formuleret som et svar på den også i tresserne udbredte tendens til at ville tænke mission og kristendom uafhængigt af et traditionelt kirkebegreb. Kyrø-Rasmussen var ikke helt afvisende over for de nye bevægelser.

En enig kirke er en utopi. Men en levende kirke, der uophørligt ser sin virksomhed efter i sømmene, er en nødvendighed. Baptister har i grunden selv peget i den sidste retning ved at hævde læren om skriften som den eneste afgørende autoritet. Man vil ikke med snævre bekendel-

20. Kyrø-Rasmussen, Hvad skal vi med kirken? (Ålborg: Baptisternes Forlag 1967). 
ser spærre vejen for de uudtømmelige skatte, der er gemt i Den hellige Skrift (Kyrø-Rasmussen 1967, 8).

Bemærkningen synes at bære spor af Mønsters oprindelige afvisning af nedskrevne bekendelser og peger på, at Kyrø-Rasmussen, hvad dette angår, i hvert fald i nogen grad var i tråd med Mønster.

Kyrø-Rasmussens stillingtagen til opgøret med den traditionelle kirke var både-og: Menneskets løsrivelse fra al påtvunget autoritet er på den ene side en udvikling, som evangeliet selv har været med til at skabe, skriver han. Men på den anden side har den moderne cartesianske tankegang med sin vægtlægning på det menneskelige subjekt betydet, at mennesket tager udgangspunkt i sig selv i stedet for evangeliet og derfor har mistet forståelsen af, hvad det vil sige at være menighed (Kyrø-Rasmussen 1967, 13).

Kritikken af cartesianismens cogito (ergo) sum og den deraf følgende individualisme ligner Martensens kritik af subjektfilosofien. Selvet etableres ikke i sin relation til sig selv, men i sin relation til andre, primært Gud. Samtidig afvises den kollektivisme, som Kyrø-Rasmussen givetvis fandt i samtidens socialistiske bevægelser (men som ikke omtales). Det bibelske perspektiv er hverken individualistisk eller kollektivistisk:

Hverken i Det Gamle Testamente eller Det ny Testamente kan man finde udtryk for en kollektivisme, der ikke afbalanceres af tanken om personligt ansvar. Medens moderne tankeformer ophøjer individ på bekostning af kollektiv eller modsat, understreges i bibelsk tankegang både individ og kollektiv. (Kyrø-Rasmussen 1967, 15)

Pointen formuleres økumenisk. Med udgangspunkt i den apostolske trosbekendelses ord om, at "vi tror på en hellig, almindelig kirke", peger Kyrø-Rasmussen på, at kirken må forstås i forlængelse af evangeliet: "At Kirken er hellig betyder, at den er en del af evangeliet, det glade budskab til frelse." (Kyrø-Rasmussen 1967, 41). Kristus er resten af Guds udvalgte folk, Israel, men med etableringen af kirken har Kristus indstiftet et folk, som får del i Kristi udvælgelse. Kristne tror på kirken, ikke som den er i sig selv, men som den er i sin relation til Gud. Det er nemlig igennem menigheden, at mennesker møder Guds gerning: "Vejen går ikke fra den enkelte til fællesskabet, men fra fællesskabet til den enkelte. Menigheden er Guds redskab til vor frelse." (Kyrø-Rasmussen 1967, 25). Som hos P. Olsen er dåben indgangen til menigheden og derfor også til kristendommen. For de første kristne var det at være kristen det samme som at være medlem af en menighed, og indgangen dertil var dåben: "Der fandtes med andre 
ord ingen kristne enere i Ny Testamente", skriver Kyrø-Rasmussen (Kyrø-Rasmussen 1967, 20).

\section{Dåb og nadver}

En udbredt kritik af baptisters dåbspraksis er, at dåben gøres til en præstation, når den forudsætter tro og bekendelse. N.H. Søe skriver $\mathrm{fx}$, at "barnedåben understreger på eftertrykkelig måde den fundamentale evangeliske sandhed, at det ikke er os, der skal finde frem til Gud eller tilkæmpe os hans velbehag, men det er ham, der uden nogen fortjeneste eller værdighed hos os kommer til os og af fri nåde tilsiger os barneret". ${ }^{21}$ Kyrø-Rasmussen synes at have haft en kritik af baptisternes dåbspraksis i stil med N.H. Søes i baghovedet i sin beskrivelse af dåben. Baptisters afvisning af barnedåben bør ikke begrundes med, skriver Kyrø-Rasmussen, at barnedåben slet ikke kan forsvares, men at den er "uklar", jf. Karl Barth (Kyrø-Rasmussen 1967, 76). Bekendelsesdåben er ikke en præstation, men en kapitulation over for Guds gerning:

Der er derfor ikke tale om at være "stor nok" for at komme til dåb - altså yde en slags åndelig præstation, før man er værdig til dåb. Lige modsat gælder det at være "lille nok" - så "lille", at man ikke vil vrage så stor en kærlighed. Til dåben kommer netop ægte mennesker, der har kastet masken og blevet hvad de er: Uden håb og uden Gud (Kyrø-Rasmussen $1967,65)$.

Dåb følger tro, men tro skal altså ikke forstås sådan, at mennesket aktivt skal vælge Gud for at modtage Kristus. Det er troen, ikke dåben, der gives ganske gratis. ${ }^{22}$ Troens forudsætning er den erkendelse af vores egen uformåenhed, der skabes af loven. Som sådan er troen netop en tillid, som følger af, at vi intet kan gøre for at retfærdiggøre os selv (Kyrø-Rasmussen 1963, 20-21). At være korsfæstet med Kristus i dåben betyder at være død fra et liv, hvor vi selv råder, for i stedet at være sammenvokset med Kristus (Kyrø-Rasmussen 1967, 69). I dåben styrkes troen gennem den troendes "oplevelse" af Kristi gerninger (Kyrø-Rasmussen 1963, 20). Man kunne måske ønske, at Kyrø-Ramussen havde valgt et andet begreb end det belastede "opleve" med dets subjektivistiske grundklang, for pointen synes netop

21. N.H. Søe ifølge Niels Anhøj, Midt $i$ mylderet (København: Føltveds Forlag 1992), 87.

22. Se også K. Kyrø-Rasmussen, Frihed, Broderskab og Efterfolgelse: Bibelstudier over Galaterbrevet, 1. Korinterbrev og Jakobs brev (København: Baptisternes forlag 1963). 
at være, at troen i dåben konkretiseres og derfor ophører med at være rent subjektiv.

Dåben er at aflægge det gamle menneske og iføre sig det nye. At leve som kristen er kontinuerligt at leve i denne "rytme", skriver Kyrø-Rasmussen. Gudstjenesten er til for at fastholde menigheden i en rytme, hvor nadveren må have en fast plads: "Nadveren som fornyelsens måltid kalder både på angeren og glæden - angeren på grund af vor afstand fra Frelseren, og glæden på grund af hans nærhed hos os. Den anger, der således er tale om, er i grunden den højeste frihed." (Kyrø-Rasmussen 1967, 97). Det centrale i gudstjenesten er dog prædikenen. Det er afgørende, at forkyndelsen ikke træder i baggrunden som noget sekundært, som i nogle kirkesamfund. Uden skrift og forkyndelse bliver dåb og nadver enten uden reelt indhold eller til "magiske" handlinger. Dåb og nadver har ikke selvstændig, mekanisk eller sakramental kraft, men er måder, hvorpå Guds Ord møder mennesket: "Det må ikke glemmes, at dåb og nadver er former for ordet, hvorved der bliver tale om Guds personlige meddelen-sig til mennesket ved gudstjenesten." (Kyrø-Rasmussen 1967, 46-47).

Der er en ikke ubetydelig sandhed i påstanden om, at en ringe kirkegang peger i retning af, at evangeliet forkyndes rent og purt, idet evangeliet aldrig er populært, skriver Kyrø-Rasmussen (et synspunkt, som ofte forbindes med tidehvervsteologi). Men det er dog en absurd ting ligefrem at gøre sig til af en ringe kirkegang: "Evangeliet er jo ikke lutter forargelse, men først og fremmest glæde. Og menigheden er ikke blot forkyndelsens produkt, men tillige dens kilde." (KyrøRasmussen 1967, 14). Menigheden er ikke blot produktet af Guds gerning, men er selve Guds gerning og det middel, igennem hvilket Gud gør sin gerning.

\section{Menighedens funktion og organisation}

Kristendom handler ikke om at stræbe efter "åndelige tinder" eller at "hæve sig op over verden og gøre sig til af sin fromhed og tro." (KyrøRasmussen 1967, 75-76). Kristendom handler tværtimod om at være kaldet til at være Guds vidne i verden: "Menigheden er med andre ord ikke "overmennesker", men døbt til at være "medmennesker" i verden. Ligesom dens Herre var til for verden, er menigheden til for verden. Den er "frelst for at tjene"." (Kyrø-Rasmussen 1967, 76-77).

At kirken er en del af evangeliet og Guds redskab til frelse betyder ikke, at menigheden for Kyrø-Rasmussen er en parallelkultur, som skal konkurrere med verdslig kultur. Det er ikke menighedens menneskelige kvaliteter, det kommer an på, men om menigheden "forkynder Kristi ord og lever af hans godhed" (Kyrø-Rasmussen 1967, 39). Hvor menigheden gør det, er den Guds gave og redskab, uanset 
hvor ringe den måtte forekomme mennesker at være. Det betyder samtidig, at kun hvor Kristi Ord ikke længere lyder, kan et menneske i Kristi navn gøre sig færdig med en menighed.

Kyrø-Rasmussen anså som andre baptister menighedens to "stedlige" embeder (præst og diakon) for at være de centrale. Der findes, skriver Kyrø-Rasmussen, både et alment præstedømme, som fx kom til udtryk i Onckens motto "Hver Baptist en Missionær", og et særligt præstedømme, som er knyttet til særlige gaver og et særligt ansvar for forkyndelse af Ordet og ledelse af menigheden. Også selvom menigheden altid er bundet til Ordet mere end til præsten (Kyrø-Rasmussen 1967, 85). Men hans kirkesyn var temmelig forskelligt fra det, der kom til udtryk i fx Jørgensen Toldams bemærkning om, at "Vi er et Missionssamfund ikke et Kirkesamfund" (M. Jørgensen Toldam ifølge Hylleberg, m.fl. 1989, 305).

I Frihed, Broderskab og Efterfølgelse advarer Kyrø-Rasmussen mod at overbetone den enkelte menigheds uafhængighed af kirkesamfundet. Den enkelte menighed er bundet til de øvrigt menigheder ved at være født af samme Ånd og antaget til tjeneste af samme Herre og bør derfor lytte til den helhed, den er en del af (Kyrø-Rasmussen 1963, 41). Dette berettiger ikke til nogen form for "kirkediktatur", som er de biskoppelige kirkers fare, understreger Kyrø-Rasmussen. Men baptisters betænkeligheder ved biskopper, der kan lede på hele kirkens vegne, har historiske snarere end bibelske grunde, hævder Kyrø-Rasmussen (Kyrø-Rasmussen 1967, 91). Generalsekretæren for baptistsamfundet fik derfor i Kyrø-Rasmussens kirkesyn en nærmest biskoppelig status, da generalsekretæren skulle forstås som hele baptistsamfundets præst.

\section{Ny narrativ personalisme?}

Kyrø-Rasmussens forståelse af menigheden som Guds redskab til at tjene verden afspejles i senere skrivelser, $\mathrm{fx}$ i folderen - om at vare menighedsmedlem, fra 1989, som i 90'erne og frem blev givet til nye medlemmer af danske baptistmenigheder. Også gudstjenestens centrale betydning understreges, idet gudstjenesten beskrives som det "centrale samlingssted i menighedens liv" hvor menigheden fornys og udrustes til at være kristne. ${ }^{23}$

23. Jan Kornholt, - om at vere menighedsmedlem (København: Føltveds forlag 1997 (1. udgave 1989)), 11. 
Tanken går igen i nyere udgivelser, fx folderen Noget om danske baptister fra 1999. Her beskrives troen som det centrale i kristendommen forstået som "et direkte forhold mellem Gud og det enkelte menneske uden behov for mellemmænd, institutioner eller bestemte ritualer af nogen art." ${ }^{24}$ Det er langt snarere "en vægtlægning på den personlige frihed end et bestemt dåbssyn eller en bestemt dåbsmåde, som forener baptisterne" (Henrik Kristiansen, m.fl. 1999, 7). Påstanden bindes op på et narrativt og kristocentrisk skriftsyn samt en skepsis over for nedskrevne trosbekendelser:

Baptister har altid anset hele Bibelen med beretningerne om Jesus i centrum som den afgørende kilde vedrørende kristen tro og liv. De søger på den måde at undgå fastlåsning og begrænsning af Bibelens budskab. I stedet er de åbne for den indsigt og forståelse, som hver eneste kristen kan få ved åbenhjertigt at læse i Bibelen. Derfor er baptister tilbageholdende over for faste formuleringer af trosbekendelser og lignende, men de fleste vil nok mene, at de klassiske kristne trosbekendelser giver et rimeligt udtryk for den kristne tros indhold (Henrik Kristiansen, m.fl. 1999, 4).

En rendyrket individualisme afvises imidlertid også: "Kristen tro er en personlig, men ikke en privat sag. Troens liv må leves i og ud fra et fællesskab af mennesker, nemlig den kristne menighed, hvori de enkelte medlemmer støtter, opmuntrer og supplerer hinanden." (Henrik Kristiansen, m.fl. 1999, 4) Det understreges, at troen ikke er noget, mennesker selv kan skabe, men at den er en gave fra Gud. Samtidig lægges der dog vægt på, at mennesker selv har ansvar for og indflydelse på "at lade troen få konsekvenser" (Henrik Kristiansen, m.fl. 1999, 4).

I folderen "FAQ om baptister" fra 2010 peger en bidragsyder på at, det "at være kirke består ikke i at få ensrettet alle holdninger, systemer og former men $\mathrm{i}$ at holde fokus på målet: At vi gennem troen på Jesus bliver ét fællesskab. Redskabet, vi skal bruge undervejs, er den samtale, vi fører med hinanden. ${ }^{25}$ Generalsekretær for Baptistkirken i Danmark Lone Møller-Hansen peger på samme måde på fællesskabets betydning for den enkeltes forståelse af sin tro: "Personlig tro er noget andet end privat tro. Når vi siger, at troen er privat, er det ofte, fordi vi er blufærdige og ikke føler os "troende nok". Jesus siger, at vi blot skal have tro som et sennepsfrø, og det er altså ikke ret stort! Personlig tro vokser ved at blive delt og ved, at vi sætter ord på det, vi tror

24. Henrik Kristiansen, m.fl., Noget om danske baptister, 2. udgave (København: Det Danske Baptistsamfund 1999), 4.

25. Andreas Højmark, "På pilgrimsvandring" i Lone Møller-Hansen, m.fl., FAQ om baptister (København: Baptistkirken i Danmark 2010), 10 
- og også deler vores tvivl med andre." (Lone Møller-Hansen, m.fl. $2010,18)$ Som hos tidligere baptister bindes denne tanke i "FAQ om baptister" sammen med en opfattelse af gudsriget som noget, der allerede er delvist realiseret. Jacob Broholm Møller skriver: "Gud selv arbejder på at forny sit skaberværk. Og det er kirkens opgave at arbejde med på denne fremtid. Kirkens budskab drejer sig om frelse. Men det er en frelse, der allerede kan erfares her og nu." Dermed er kursen også udstukket for engagement i forskellige miljømæssige og politiske sager (Lone Møller-Hansen, m.fl. 2010, 31).

Som i Folkekirken har et væsentligt debatpunkt i den danske baptistkirke de senere år været vielser af homoseksuelle, og som i resten af samfundet findes der flere meninger, selvom danske baptister nok hælder til den konservative side. Teologisk Forum (en arbejdsgruppe under Baptistkirken i Danmark) anbefalede i 2012 at acceptere, hvad man kaldte en "kvalificeret 'etisk uenighed", idet baptister må finde ud af at have fællesskab trods vidt forskellige meninger. ${ }^{26} \mathrm{Kun}$ få menigheder, fx Immanuelskirken i Aarhus, har indført vielser af homoseksuelle. Købnerkirken på Amager besluttede i 2014 derimod ikke at have en officiel holdning til homoseksuelle vielser. I stedet overlod man vielser til rådhuset for til gengæld selv at velsigne parforhold uden skelen til køn. Vielse bør være "en borgerlig handling, der finder sted på borgmesterkontoret”, hedder det i Købnerkirkens udtalelse. Det understreges, at modstanden mod at foretage vielse med borgerlig gyldighed "absolut intet" har at gøre med en bestemt holdning til homoseksualitet, men alene har med "stat-kirke spørgsmålet at gøre”. Købnerkirkens beslutning kan dog, mener jeg, forstås som et vellykket forsøg på at komme uden om overflødige teologiske og kirkepolitiske disputter. Under overskriften "Jeg er så træt af kristnes diskussion om homoseksualitet" skriver præst Jan Kornholt, at friheden til selv at tolke Bibelen og tage personlig stilling også indebærer en frihed til, at mennesker "kan træffe forskellige valg og alligevel være fuldt og helt med i fællesskabet." ${ }^{27}$ Ingen kristne har ret til at have mere ret end andre, som det hedder.

I en af Købnerkirkens beskrivelser af, hvad der kendetegner en baptistkirke hedder det, at "Bibelen er vigtigste norm for vores tro og liv". Men straks derefter slås det fast, at dette indebærer "Personlig frihed til selv at tolke Bibelen og selv at vælge tro og livsstil". ${ }^{28}$ Pointen synes kort sagt at være, at fordi skriften er det grundlæggende princip, kan

26. Se Bent Hylleberg, m.fl., Til danske baptistmenigheder: om homoseksuelles plads $i$ menigheden (Teologisk Forum i Baptistkirken i Danmark 2012)

27. Se http://koebnerkirken.dk/praestetanker/jeg-er-sa-traet-af-kristnes-diskussion-om-homoseksualitet/ (besøgt 06.04.15).

28. Se http://koebnerkirken.dk/faq/ (tilgået d. 6/4-2015) 
ingen bestemt udlægning af skriften gøres mere autoritativ end andre. Der er ingen norm, som skal normeres, ingen norma normata (det skulle da lige være den kristnes personlige livsfortælling). Man kan derfor heller ikke kræve enighed om udlægningen af troen, men kun om hvad der gælder som autoritet for udlægning af troen. Derfor skal diskussioner om $\mathrm{fx}$ vielser af homoseksuelle ikke løses teologisk, men ved at opløse de formelle omstændigheder, der i første omgang har gjort kontroverser mulige.

\section{Konklusion}

Ovenfor er jo egentlig ikke sagt så meget om teologiens faktiske indhold, men kun om hvilke rammer, der er for refleksion over troen. Igen er der tale om en ekklesiologi, et kirkesyn, snarere end en dogmatik. Konfessionalisme og fundamentalisme (i ordets præcise forstand) er en sjældenhed blandt danske baptister, hvis trossyn langt bedre indfanges af McClendons begreb om "small b baptists." McClendons opfattelse ligner i høj grad begrebet om "åben baptisme". ${ }^{29}$ Tanken om "biografi som teologi" beskriver også godt fx P.C. Mønsters forståelse af trosbekendelse som det at fortælle sit "levnedsløb", P. Olsens "personlige forhold" til Gud og Kyrø-Rasmussens dobbelte afvisning af individualisme og kollektivisme til fordel for et personligt og relationelt trossyn.

Jeg har ovenfor berørt en række forskellige teologiske tankestrømninger. Jeg har ikke berørt, hvordan orienteringen omkring "det personlige" i vid udstrækning kan betegnes som en aflejring af elementer fra det 19. århundredes liberalteologiske strømninger eller lignende. Men den lidt overfladiske gennemgang skulle dog gerne gøre det klart, at det "personalistiske" og det "narrative" på forskellig vis kan genfindes ikke mindst i den stadige skepsis over for fastlagte trosbekendelser, og at vi derfor med rette kan tale om, at danske baptisters teologi historisk og i dag er kendetegnet ved det, jeg har kaldt "narrativ personalisme". Denne tankegang kan spores tilbage til grundlæggelsen af de første danske baptistmenigheder, som, selvom de i høj grad er fulgt med tiden, har fastholdt et afgørende grundprincip - nemlig den enkeltes frihed til selv at formulere og sætte begreb på sin tro i fællesskab med andre troende.

29. I øvrigt svarer begrebet "small b baptists" jo helt naturligt til en dansk sammenhæng, hvor "baptist" og "baptister" helt naturligt efter retskrivningsreformen i 1948 staves med småt, og hvor begrebet i modsætning til en amerikansk sammenhæng typisk anvendes bredt til også at omfatte reformationens døbere. 